\title{
Resources for British butterflies (Lepidoptera: Hesperioidea, Papilionoidea). The alien consumer component and its significance for butterfly habitats
}

\author{
Peter B. HARDY ${ }^{1}$ and Roger L.H. DENNIS ${ }^{2 *}$ \\ ${ }^{1} 81$ Winstanley Road, Sale M33 2AT, UK
}

${ }^{2}$ NERC Centre for Ecology and Hydrology, Monks Wood, Abbots Ripton, Huntingdon, Cambridgeshire PE28 2LS, U.K. and Institute for Environment, Sustainability and Regeneration, Mellor Building, Staffordshire University, College Road, Stoke on Trent, ST4 2DE, UK

Key words. Lepidoptera, biotope, distributions, habitat, gardens, geographical range, introductions, migration

\begin{abstract}
With climatic warming there is an expectation that phytophagous insects will increasingly use alien (non native) plants as nectar sources and larval host plants. Alien plant use is investigated in British butterflies. Butterflies are considered to be larval host plant specialists relative to their use of nectar plants. Supporting this view, use of alien plants as nectar sources $(50.1 \%, 27$ novel plant families) is almost twice that of their use as larval host plants (21.6\%; three novel plant families). Some $80 \%$ of the variation in percent alien nectar plant use is accounted against 30\% of that for percent alien host plant use. The key variable accounting for alien plant use is butterfly mobility. Other prominent variables that facilitate access to alien nectar plants are southern distributions, longer adult life span, host plants in garden biotopes. A different set of variables additionally account for alien host plant exploitation (\% alien host plant use: woody host plants; number of alien host plants: polyphagy; greater abundance of native host plants in gardens). Although threatened butterfly species do not depend on alien plants, this may well reflect on specialisation in resource use accompanying habitat fragmentation and an inability to use novel resources that are becoming increasingly available. Detailed study of alien resources is advocated to assess the importance of alien plant resources for phytophagous insects.
\end{abstract}

\section{INTRODUCTION}

Alien plants are rapidly becoming an important conservation issue in many parts of the world (e.g. Asia, Ricklefs et al., 2008; South Africa, Rebelo, 1992; Foxcroft et al., 2008; North America, DiTommaso et al., 2005; Wells et al., 2007; Europe, Chytry et al., 2008). Native insects are increasingly colonising the alien plants (Kenis et al., 2007) and alien insects often accompany their introductions (Smith et al., 2007). Among users of alien plants are butterflies; alien plants can be important larval hosts and nectar sources (Bowers et al., 1992b; Singer et al., 1993; Pryke \& Samways, 2003; Graves \& Shapiro, 2003; DiTommaso et al., 2005; Hardy \& Dennis, 2008) though they can also be toxic to butterfly species (Graves \& Shapiro, 2003).

British butterflies have long been known to use alien (non native) plants as nectar sources (e.g. Michaelmas daisy, Aster x salignus; buddleia, Buddleja davidii) and to breed successfully on some alien larval host plants, both in captivity (e.g. several Lycaenidae on Pisum sativum L. Fabaceae) and without intervention in gardens and the open countryside (e.g. Pieris brassicae on Tropaeolum species). With the increase of alien plants in nurseries and suburban gardens, their invasion of open countryside, the use of alien plants is likely to increase, an exploitation that may well be encouraged by climatic warming. An opportunity has arisen to review this issue with the development of a consumer data base for British butterflies (Dennis et al., 2008).
Several obvious questions arise from the use of alien plants. First, to what extent are alien plants exploited as adult and larval resources? Is the fraction large or small, and does it differ substantially between the two resource types? Secondly, following on from this, does the use of alien plants open up unusual biotopes (e.g. gardens, motorway embankments) as habitats and provide important supplementary resources within biotopes already occupied? The answer to this question likely lies partly in butterfly life history associations and partly in the opportunities available to species. It inevitably raises a third question: what agents influence alien nectar and larval host plant use? Clearly, opportunities to use alien plants are likely to be increased by a number of factors; such are distribution cover and geographical range, the number of plants (host plants and nectar plants) used already, and mobility, which determines the capacity to explore new biotopes especially gardens and parks where new plants are typically introduced.

This short communication attempts to provide some answers to these questions by inspection of the developing larval host plant and adult feeding database.

\section{DATA SOURCES AND TREATMENT}

Data on consumer resources have been accumulated for the purpose of developing a resource database on British butterflies; details are outlined in Dennis et al. (2008); these files can be accessed at: www.geocities.com/pgll@btopenworld.com/ resources/resources.htm.

\footnotetext{
* Correspondence: R.L.H. Dennis, 4 Fairfax Drive, Wilmslow, Cheshire SK9 6EY, UK; e-mail: rlhdennis@aol.com
} 
Data on adult feeding now extend to 11,261 records and 106,842 observations $(57,372$ observations lacking counts are regarded each as single observations) on 74 butterfly species and 531 plant "taxa" (435 if those listed as of unknown species or as broad groups are omitted) as of January $12008 ; 11,176$ records for the 60 butterflies that breed in Britain. The adult feeding data have been accumulated from 372 sources, largely unpublished. The host plant data comprise 5,595 records $(5,321$ for the breeding species) extracted from 196 sources that are mainly published. Nectar and host plant sources are distinguished as "native" or "alien" (i.e. non native, either deliberate or accidental introductions to the British Isles; see http:// www.brc.ac.uk/resources.htm English Nature non-native audit report 662 for species occurring in England). Host plant status is further designated into main and subsidiary (auxiliary or secondary and generally regarded as insufficient without the presence of main host plants). The two files on nectar and host plant sources are not entirely, nor equally, reliable. The file for host plants has a long history, many of the plants identified during autecological survey, and the records largely reliable. In the following comparisons, it is understood that neither the larval host plant file nor the adult feeding file is the result of a systematic field survey and that the nectar plant data is likely biased more to observations made in gardens than the larval host plant data.

The nomenclature for butterfly species follows Asher et al. (2001) and that for plant species, Stace (1997). Designation of plants as native and alien is also taken from Stace. Butterflies and most native plants returned soon after the Devensian maximum glaciation (18 ka BP) and/or Loch Lomond Readvance (circa 10 ka BP; Godwin, 1984; Dennis, 1977, 1993). Alien is taken to mean introduced to a region (Britain) deliberately or accidentally by man. In some cases this designation is uncertain; a classic case is Brassica oleracea which occurs on cliffs and may have done so for much of the Holocene. Variables are described in Table 1 with their transforms for normality. Analyses are conducted in STATISTICA (Statsoft Inc.) and significance is taken as $\mathrm{P}<0.05$.

An important proviso of this study is that an important distinction has necessarily to be drawn between the numbers and proportions of alien plants used by butterflies; these variables do not necessarily measure quite the same usage of alien plants; a correlation between numbers and proportions may not be close. Both are examined; for the former, poisson log-link regression is the most appropriate model, and for the latter, the proportions are arcsine transformed and the regressions weighted for number of plants (native nectar plants and native host plants respectively).

\section{HYPOTHESES AND METHODS}

The study examines three broad issues, a comparison of alien nectar and host plant sources, factors influencing alien plant use,

TABLE 1. Variables for British butterflies.

Variables (description) [transform when applied] (source)

(i) Butterfly alien host plant and nectar plant variables

Number of alien host plants (number) [Ln] ${ }^{1}$

Number of alien nectar plants (number) $[\mathrm{Ln}]^{1}$

Alien host plants (proportion of total host plants) [Arcsine ${ }^{1}$

Alien nectar plants (proportion of total nectar plants) [Arcsine] ${ }^{1}$

(ii) Other butterfly host plant, nectar plant and resource variables

Total number of native host plants (number) $[\mathrm{Ln}]^{1}$

Total number of native nectar plants (number) $[\mathrm{Ln}]^{1}$

Nectar specialisation (number of nectar plants standardised on number of adult feeding records) ${ }^{1}$

Number of utility resources used (number of structural resources used by different developmental stages) (Dennis et al., 2004)

Larval host plant growth form (mean of 1 herbs, 2 shrubs, 3 climbers and 4 trees) [ $\log _{10}$ (Dennis et al., 2004)

Phagy (ranked into 1 monophags, 2 oligophag I, 3 oligophag II, 4 polyphag; sensu Wiklund, 1981) (Dennis et al., 2004)

(iii) Biotope variables

Number of biotopes occupied (number) [Ln] (Dennis et al., 2004) ${ }^{2}$

Garden biotopes (abundance of host plants in biotope) (Dennis et al., 2004) ${ }^{2}$

Wasteland biotopes (abundance of host plants in biotope) (Dennis et al., 2004) ${ }^{2}$

Spoil biotopes (abundance of host plants in biotope) (Dennis et al., 2004) ${ }^{2}$

Skeletal soil biotopes (abundance of host plants in biotope) (Dennis et al., 2004) ${ }^{2}$

Arable biotopes (abundance of host plants in biotope) [Ln] (Dennis et al., 2004) ${ }^{2}$

Pasture biotopes (abundance of host plants in biotope) (Dennis et al., 2004) ${ }^{2}$

Woodland biotopes (abundance of host plants in biotope) [Ln] (Dennis et al., 2004) ${ }^{2}$

(iv) Butterfly morphology and life history variables

Proboscis length (mm) [Ln] (Dennis et al., 2004)

Adult life span (maximum, days) [Ln] (Dennis et al., 2004)

Voltinism (1, 1 brood, 2, >1 brood each year) (Dennis et al., 2004)

Mobility (9 point scale) [Ln] (Dennis et al., 2004)

Flight period (total of broods, days) [Ln] (Dennis et al., 2004)

(v) Butterfly distribution, range and conservation status variables

Distribution cover of butterfly species (10 km squares occupied) [square root] (from Fox et al., 2006)

Latitude of butterfly distribution (median between northernmost and southernmost point on the British mainland) (from Asher et al., 2001; Fox et al., 2006)

Decline (distribution decline, scaled 0 (none) to 100 (maximum observed) (from distribution losses in Fox et al., 2006)

BAP status (Biodiversity Action Plan priority status; coded 0 none, 1 priority) (Fox et al., 2006)

${ }^{1}$ www.geocities.com/pgll@btopenworld.com/resources/resources.htm. ${ }^{2}$ Mean score for abundance of all host plants occurring in the biotope, each scored 1 to 5. Many of the variables are taken from Dennis et al., 2004 which gives detailed descriptions of them. 
and links between alien plant use, butterfly geography and conservation status.

\section{Comparison of alien nectar and larval host plant sources}

A comparison is made of the use of alien plant sources (species, families) for nectar feeding and larval development. As butterfly adults are known to be relatively greater generalist consumers compared to larvae (Ehrlich \& Raven, 1965), it is expected that alien plants form a significantly larger proportion of food for adults than they do for larvae. As the number of larval host plants is less than the number of nectar source plants, a comparison of proportions ( $\% \mathrm{~s})$ is made using the Wilcoxon Matched Pairs test.

\section{Exploring associations in the extent of alien plant use}

Associations are then explored for alien plant use, among biotopes, their life history, geography and conservation status. It is expected that consumer generalist butterfly species (using more native plants) exploit a greater fraction of alien plants than consumer specialists. This is investigated directly for both host plants and nectar plants by correlation and regression. Spearman correlations are used to report initially on simple associations; these give conservative estimates for proportions (affected by small numbers of cases) and for counts when tied ranks are frequent, as for alien host plants, where a number of butterfly species use none.

\section{Investigation of links between alien plant use, butterfly dis-} tributions and conservation status

It is also expected that butterflies that use more alien plants will have wider distributions, occupy more biotopes (especially gardens where many introduced plants are cultivated), have wider ecological niches, greater mobility, and more broods (Dennis et al., 2004). Butterflies that use more alien nectar sources should also have longer flight periods, longer adult life span, and have longer proboscises; they have greater opportunity for exploiting a wider variety of nectar plants. Insufficient data are available for assessing any influence of wing loading (viz. body mass/wing expanse) which is known to influence use of nectar plants varying in flower density and corolla depth (Corbet, 2000) and make sense of taxonomic affiliations between nectar plant and butterfly. Greater relative use of alien plants should also equate with lower distributional losses and lower conservation status (Biodiversity Action Plan, BAP; Fox et al., 2006). Broad associations are sought using principal components analysis (PCA) and contributions to variation in use explored using regression analyses. In the PCA, variables form columns and butterfly species rows in the spreadsheet; nectar and host plant alien variables are entered supplementary to an analysis based on potential predictor variables (e.g. biotopes, life history variables).

\section{RESULTS}

\section{Comparison of alien nectar and larval host plant sources}

The 60 native British butterflies are currently known to use 269 larval host plants (with species clearly distinguished), 89 of which are key to persistence in habitats; 58 are alien comprising $21.6 \%$ of the total. By comparison, the list for alien nectar flower sources includes 435 species (531 plant groups including those not distinguished to species level), 218 alien and 217 native (50.1\%; 273 versus 251, 7 uncertain, for less clearly defined plant groups). Compared across species, alien nectar plants form a significantly more substantial com-

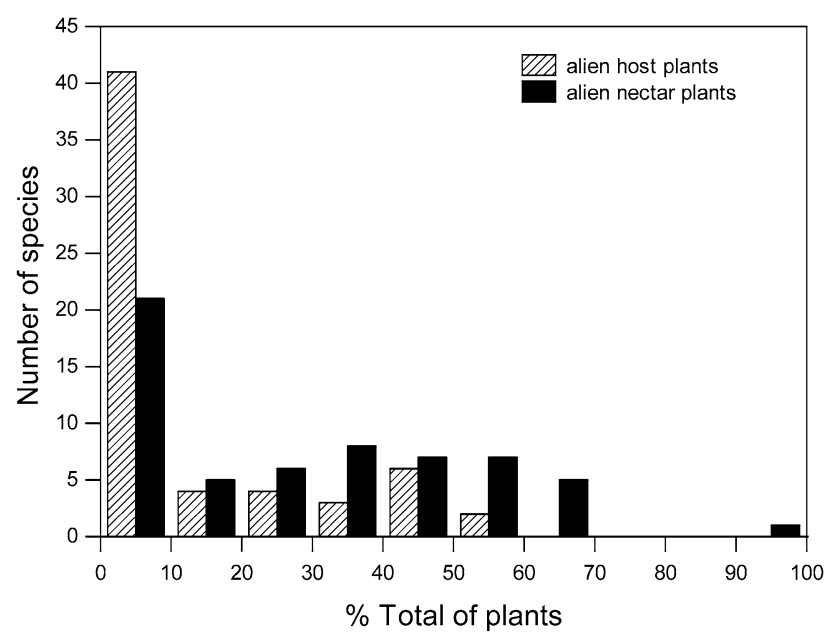

Fig. 1. Frequency distribution for the exploitation of alien nectar plants and larval host plants by British butterflies $(\mathrm{N}=60$ species).

ponent of adult resource use in Britain than do alien larval host plants (Wilcoxon Matched Pairs Test: $\mathrm{T}=193.0, \mathrm{Z}=$ $3.80, \mathrm{P}=0.0002, \mathrm{~N}=60$; median alien host plants $0 \%$, host plants $27.9 \%$; Table 2 and Fig. 1).

Among alien host plants adopted, only three new plant families are represented: Tropaeolaceae $(P$. brassicae, $P$. rapae, $P$. napi, $A$. cardamines), Capparacaceae ( $P$. brassicae, $P$. rapae) and Buddlejaceae ( $C$. argiolus), seven occurrences among butterfly species compared to a total of 84 , indicating stability in adoption of host plant family $\left(\chi_{(1)}^{2}=33.31, \mathrm{P}<0.0001\right)$ (Table 3$)$. Use of alien nectar sources has resulted in a substantial increase in the number of plant families represented as nectar sources, an addition of a further 21 families (Table 4). Some of these families have native plants in Britain not noted yet as nectar sources. Even so, there is no difference in the relative frequency (observations as percentages of total for each group, $\mathrm{n}=1790$ native and 1455 alien) with which families are exploited as nectar sources (Wilcoxon Matched Pairs Test, $\mathrm{T}=1306, \mathrm{Z}=0.63, \mathrm{P}=0.53$ ).

\section{Exploring associations in the extent of alien plant use}

Across all species, the proportion of host plants that are alien does not correlate with total number of native host plants (Spearman $r_{s}=-0.01, P=0.97$ ) nor with the total number of native nectar plants $\left(\mathrm{r}_{\mathrm{s}}=0.13, \mathrm{P}=0.30\right)$. On the other hand, the proportion of nectar plants that are alien correlates significantly with total number of native nectar plants used $\left(\mathrm{r}_{\mathrm{s}}=0.64, \mathrm{P}<0.0001\right)$ and significantly with the total number of native larval host plants $\left(r_{\mathrm{s}}=\right.$ $0.40, \mathrm{P}=0.001)$. There is a significant correlation in proportional use of alien nectar plant and alien host plants $\left(\mathrm{r}_{\mathrm{s}}\right.$ $=0.26, \mathrm{P}=0.04$ ).

The order of relationships (correlations) and pattern of significances are similar for actual numbers of alien plants (Spearman $r_{s}$ : alien host plants with total native host plants, $\mathrm{r}_{\mathrm{s}}=0.18, \mathrm{P}=0.17$; alien host plants with total nectar plants, $\mathrm{r}_{\mathrm{s}}=0.24, \mathrm{P}=0.07$; alien nectar plants with total native nectar plants, $\mathrm{r}=0.84, \mathrm{P}<0.0001$; alien nectar plants with total host plants, $\mathrm{r}_{\mathrm{s}}=0.47, \mathrm{P}=0.0002$ ). 
TABLE 2. Numbers of alien and total nectar and host plants used by British butterflies.

\begin{tabular}{|c|c|c|c|c|}
\hline Species $^{1}$ & $\begin{array}{l}\text { Number of alien larval } \\
\text { host plants (\% of total) }\end{array}$ & $\begin{array}{c}\text { Total number of larval } \\
\text { host plants }\end{array}$ & $\begin{array}{l}\text { Number of alien nectar } \\
\text { source plants (\% of total) }\end{array}$ & $\begin{array}{l}\text { Total number } \\
\text { of nectar plants }{ }^{2}\end{array}$ \\
\hline Carterocephalus palaemon & $0(0)$ & 3 & $0(0)$ & 7 \\
\hline Thymelicus sylvestris & $0(0)$ & 9 & $37(34.9)$ & 69 \\
\hline Thymelicus lineola & $0(0)$ & 9 & $9(31.0)$ & 20 \\
\hline Thymelicus acteon & $0(0)$ & 3 & $0(0)$ & 13 \\
\hline Hesperia comma & $0(0)$ & 2 & $2(14.3)$ & 12 \\
\hline Ochlodes sylvanus & $0(0)$ & 10 & $33(37.9)$ & 54 \\
\hline Erynnis tages & $0(0)$ & 3 & $0(0)$ & 18 \\
\hline Pyrgus malvae & $1(8.3)$ & 12 & $0(0)$ & 20 \\
\hline Papilio machaon & $4(57.1)$ & 7 & $2(10.5)$ & 17 \\
\hline Leptidea sinapis & $3(37.5)$ & 8 & $2(6.3)$ & 30 \\
\hline Colias croceus & $2(16.7)$ & 12 & $16(34.8)$ & 30 \\
\hline Gonepteryx rhamni & $2(50.0)$ & 4 & $40(48.2)$ & 43 \\
\hline Pieris brassicae & $14(56.0)$ & 25 & $106(60.2)$ & 70 \\
\hline Pieris rapae & $12(48.0)$ & 25 & $129(56.3)$ & 100 \\
\hline Pieris napi & $8(36.4)$ & 22 & $77(46.7)$ & 88 \\
\hline Anthocharis cardamines & $9(29.0)$ & 31 & $24(41.4)$ & 34 \\
\hline Callophrys rubi & $0(0)$ & 23 & $7(22.6)$ & 24 \\
\hline Thecla betulae & $1(50.0)$ & 2 & $1(10.0)$ & 9 \\
\hline Neozephyrus (Quercusia) quercus & $2(50.0)$ & 4 & $6(37.5)$ & 10 \\
\hline Satyrium w-album & $1(25.0)$ & 4 & $11(32.4)$ & 23 \\
\hline Satyrium pruni & $1(50.0)$ & 2 & $0(0)$ & 8 \\
\hline Lycaena phlaeas & $0(0)$ & 5 & $53(52.0)$ & 49 \\
\hline Lycaena dispar & $0(0)$ & 1 & $0(0)$ & 4 \\
\hline Cupido minimus & $1(50.0)$ & 2 & $0(0)$ & 4 \\
\hline Plebejus argus & $0(0)$ & 16 & $11(40.7)$ & 16 \\
\hline Aricia agestis & $0(0)$ & 6 & $7(26.9)$ & 19 \\
\hline Aricia artaxerxes & $0(0)$ & 3 & $0(0)$ & 4 \\
\hline Polyommatus icarus & $1(9.1)$ & 11 & $45(42.1)$ & 62 \\
\hline Polyommatus (Lysandra) coridon & $1(12.5)$ & 8 & $4(19.0)$ & 17 \\
\hline Polyommatus (Lysandra) bellargus & $0(0)$ & 2 & $1(5.9)$ & 16 \\
\hline Celastrina argiolus & $9(37.5)$ & 24 & $85(60.3)$ & 56 \\
\hline Maculinea arion & $0(0)$ & 2 & $0(0)$ & 4 \\
\hline Hamearis lucina & $0(0)$ & 4 & $0(0)$ & 11 \\
\hline Limenitis camilla & $0(0)$ & 1 & $3(27.3)$ & 8 \\
\hline Apatura iris & $0(0)$ & 3 & $2(100)$ & 0 \\
\hline Vanessa atalanta & $1(20.0)$ & 5 & $86(69.9)$ & 37 \\
\hline Vanessa cardui & $5(18.5)$ & 27 & $58(55.8)$ & 46 \\
\hline Aglais urticae & $0(0)$ & 2 & $129(60.0)$ & 86 \\
\hline Nymphalis polychloros & $4(22.2)$ & 18 & $6(60.0)$ & 4 \\
\hline Inachis io & $0(0)$ & 3 & $90(60.4)$ & 59 \\
\hline Polygonia c-album & $2(25.0)$ & 8 & $68(60.2)$ & 45 \\
\hline Boloria selene & $0(0)$ & 6 & $3(10.3)$ & 26 \\
\hline Boloria euphrosyne & $0(0)$ & 7 & $0(0)$ & 18 \\
\hline Argynnis adippe & $0(0)$ & 5 & $2(10.0)$ & 18 \\
\hline Argynnis aglaja & $0(0)$ & 6 & $5(17.9)$ & 23 \\
\hline Argynnis paphia & $0(0)$ & 3 & $9(31.0)$ & 20 \\
\hline Euphydryas aurinia & $0(0)$ & 9 & $0(0)$ & 19 \\
\hline Melitaea cinxia & $0(0)$ & 6 & $0(0)$ & 10 \\
\hline Melitaea (Mellicta) athalia & $0(0)$ & 10 & $0(0)$ & 25 \\
\hline Pararge aegeria & $0(0)$ & 13 & $53(58.9)$ & 37 \\
\hline Lasiommata megera & $0(0)$ & 12 & $43(48.9)$ & 45 \\
\hline Erebia epiphron & $0(0)$ & 2 & $0(0)$ & 5 \\
\hline Erebia aethiops & $0(0)$ & 8 & $0(0)$ & 20 \\
\hline Melanargia galathea & $0(0)$ & 8 & $10(29.4)$ & 24 \\
\hline Hipparchia semele & $0(0)$ & 12 & $8(28.6)$ & 20 \\
\hline Pyronia tithonus & $0(0)$ & 11 & $76(59.8)$ & 51 \\
\hline Maniola jurtina & $0(0)$ & 15 & $45(40.9)$ & 65 \\
\hline Aphantopus hyperantus & $0(0)$ & 12 & $19(38.0)$ & 31 \\
\hline Coenonympha pamphilus & $0(0)$ & 8 & $16(26.2)$ & 45 \\
\hline Coenonympha tullia & $0(0)$ & 6 & $0(0)$ & 12 \\
\hline
\end{tabular}


TABLE 3. Observations on plant families used as host plant sources by British butterflies.

\begin{tabular}{|c|c|c|c|}
\hline Family & Native & Alien & Total \\
\hline Ulmaceae & 3 & 1 & 4 \\
\hline Cannabaceae & 1 & 0 & 1 \\
\hline Urticaceae & 3 & 1 & 4 \\
\hline Fagaceae & 2 & 2 & 4 \\
\hline Betulaceae & 1 & 0 & 1 \\
\hline Polygonaceae & 5 & 0 & 5 \\
\hline Malvaceae & 2 & 0 & 2 \\
\hline Cistaceae & 2 & 0 & 2 \\
\hline Violaceae & 9 & 0 & 9 \\
\hline Salicaceae & 7 & 1 & 8 \\
\hline Capparaceae & 0 & 1 & 1 \\
\hline Brassicaceae & 27 & 17 & 44 \\
\hline Resedaceae & 2 & 1 & 3 \\
\hline Empetraceae & 1 & 0 & 1 \\
\hline Ericaceae & 7 & 0 & 7 \\
\hline Primulaceae & 4 & 0 & 4 \\
\hline Grossulariaceae & 1 & 2 & 3 \\
\hline Rosaceae & 14 & 9 & 23 \\
\hline Fabaceae & 26 & 8 & 34 \\
\hline Lythraceae & 1 & 0 & 1 \\
\hline Cornaceae & 1 & 0 & 1 \\
\hline Celastraceae & 1 & 0 & 1 \\
\hline Aquifoliaceae & 1 & 0 & 1 \\
\hline Rhamnaceae & 2 & 2 & 4 \\
\hline Geraniaceae & 6 & 0 & 6 \\
\hline Tropaeolaceae & 0 & 2 & 2 \\
\hline Araliaceae & 1 & 0 & 1 \\
\hline Apiaceae & 3 & 4 & 7 \\
\hline Boraginaceae & 2 & 1 & 3 \\
\hline Lamiaceae & 3 & 0 & 3 \\
\hline Plantaginaceae & 4 & 0 & 4 \\
\hline Buddlejaceae & 0 & 1 & 1 \\
\hline Scrophulariaceae & 7 & 0 & 7 \\
\hline Caprifoliaceae & 3 & 1 & 4 \\
\hline Dipsaceae & 3 & 0 & 3 \\
\hline Asteraceae & 15 & 4 & 19 \\
\hline Juncaceae & 1 & 0 & 1 \\
\hline Cyperaceae & 3 & 0 & 3 \\
\hline Poaceae & 37 & 0 & 37 \\
\hline
\end{tabular}

39 plant families. Numbers are records for butterfly species.

Numbers of alien host plants is correlated with alien nectar plants $\left(\mathrm{r}_{\mathrm{s}}=0.34, \mathrm{P}=0.008\right)$.

The parametric relationship between proportion of alien nectar plants used and number of native nectar plants is affected particularly by the position of Apatura iris; this species gives aberrant results as it typically feeds on nonflower resources (sap, corpses, faeces etc) and has only ever been recorded feeding on two alien flowering plants in Britain. The removal of $A$. iris from the regression of proportional use of alien nectar plants on number of native nectar plants produces a single outlier (standardised residual $>|2|$ ) in $N$. polychloros, suggesting an underestimate of native nectar sources used; a number of other species have fewer (e.g. M. athalia, E. aurinia) or more (e.g. L. camilla, P. argus) alien species than expected based simply on the total number of nectar plants used (Fig. 2).

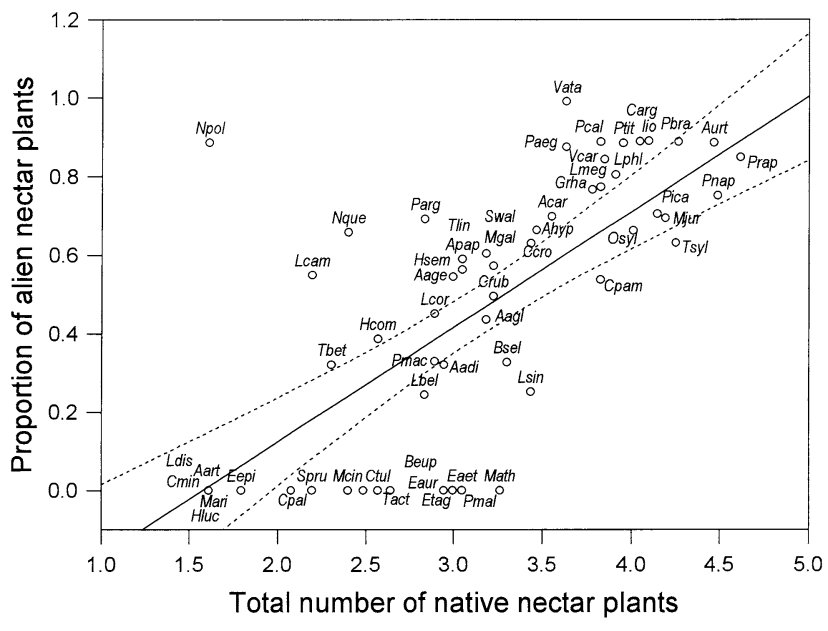

Fig. 2. Relationship between proportion of alien nectar plants (arcsine transformed) and the total number of native nectar plants (log transformed) exploited by British butterflies (A. iris removed): $F_{(1,57)}=52.78, P<0.0001$, Standard error of estimate $0.25, R=0.69, R^{2}=48 \%$ ). Species labels include the first letter of the genus and the first three letters of the species (see Table 2).

\section{Investigation of links between alien plant use, butterfly distributions and conservation status}

The principal components two dimensional plot contains $53 \%$ of the variance; each subsequent vector accounts for $<10 \%$ of the variance (Fig. 3). Alien nectar plants (numbers and proportions) load highly on vector 1 (loadings $-0.79,-0.89$ ) and are closely related to total numbers of nectar plants, the mobility, distribution cover and range of butterfly species. Alien host plants have modest loadings on both vectors (loadings $-0.45,-0.22$ ) and have their closest relationships with woodland and garden biotopes, host plant growth form, and adult life span. Species with greater number of alien plants show least distributional decline and do not have BAP priority status.

Regression analysis accounted for $80.5 \%$ of the variation for the proportion of nectar plants that are alien; the key predictor is mobility with significant contributions added from host plant abundance in garden and arable biotopes, the latitude of the butterfly distribution and adult life span (Table 5). An increase in all predictors is associated with an increase in the proportional use of nectar plant species with the exception of the median tendency in butterfly latitudinal range where butterflies with more southern distributions use more alien nectar plants. Total number of native nectar plants was not entered as this may well have reflected on both mobility and distribution cover but the regression was weighted by number of native nectar plants (Hardy et al., 2007). A smaller proportion of alien host plants is explained $(30 \%)$ by mobility and larval host plant growth form; species which are more mobile and use tree and shrub host plants have adopted proportionately more alien host plants. No analysis was made of the actual number of alien nectar plants adopted as this is closely related to total number of native nectar plants used. A poisson log-link regression 
TABLE 4. Observations on plant families used as nectar sources by British butterflies.

\begin{tabular}{|c|c|c|c|}
\hline Family & Native & Alien & Total \\
\hline Brassicaceae & 31 & 156 & 187 \\
\hline Euphorbiaceae & 3 & 1 & 4 \\
\hline Rosaceae & 116 & 70 & 186 \\
\hline Scrophulariaceae & 23 & 36 & 59 \\
\hline Lamiaceae & 186 & 90 & 276 \\
\hline Crassulaceae & 2 & 26 & 28 \\
\hline Asteraceae & 636 & 395 & 1031 \\
\hline Fabaceae & 154 & 64 & 218 \\
\hline Caprifoliaceae & 10 & 23 & 33 \\
\hline Hippocastanaceae & 0 & 1 & 1 \\
\hline Liliaceae & 27 & 37 & 64 \\
\hline Boraginaceae & 35 & 26 & 61 \\
\hline Ranunculaceae & 52 & 15 & 67 \\
\hline Asclepiadaceae & 0 & 2 & 2 \\
\hline Saxifragaceae & 0 & 10 & 10 \\
\hline Apiaceae & 50 & 9 & 59 \\
\hline Chenopodiaceae & 1 & 2 & 3 \\
\hline Buddlejaceae & 0 & 57 & 57 \\
\hline Myrtaceae & 0 & 1 & 1 \\
\hline Ericaceae & 52 & 8 & 60 \\
\hline Convolvulaceae & 6 & 6 & 12 \\
\hline Campanulaceae & 2 & 25 & 27 \\
\hline Verbenaceae & 1 & 45 & 46 \\
\hline Fagaceae & 0 & 1 & 1 \\
\hline Rhamnaceae & 3 & 12 & 15 \\
\hline Valerianaceae & 3 & 31 & 34 \\
\hline Plumbaginaceae & 16 & 19 & 35 \\
\hline Rutaceae & 0 & 7 & 7 \\
\hline Clethraceae & 0 & 4 & 4 \\
\hline Iridaceae & 2 & 4 & 6 \\
\hline Thymelaeaceae & 1 & 1 & 2 \\
\hline Hydrangaceae & 0 & 15 & 15 \\
\hline Caryophyllaceae & 56 & 40 & 96 \\
\hline Grossulariaceae & 2 & 17 & 19 \\
\hline Papaveraceae & 1 & 1 & 2 \\
\hline Polygonaceae & 11 & 6 & 17 \\
\hline Sterculiaceae & 0 & 2 & 2 \\
\hline Onagraceae & 27 & 2 & 29 \\
\hline Geraniaceae & 27 & 11 & 38 \\
\hline Polemoniaceae & 1 & 27 & 28 \\
\hline Malvaceae & 2 & 13 & 15 \\
\hline Balsaminaceae & 0 & 15 & 15 \\
\hline Oleaceae & 12 & 30 & 42 \\
\hline Atherospermataceae & 0 & 4 & 4 \\
\hline Lauraceae & 0 & 1 & 1 \\
\hline Linaceae & 2 & 1 & 3 \\
\hline Primulaceae & 16 & 7 & 23 \\
\hline Berberidaceae & 1 & 3 & 4 \\
\hline Apocynaceae & 0 & 4 & 4 \\
\hline Solanaceae & 0 & 11 & 11 \\
\hline Oxalidaceae & 0 & 3 & 3 \\
\hline Paeoniaceae & 0 & 1 & 1 \\
\hline Passifloraceae & 0 & 1 & 1 \\
\hline Rubiaceae & 12 & 3 & 15 \\
\hline Pittosporaceae & 0 & 1 & 1 \\
\hline Resedaceae & 0 & 4 & 4 \\
\hline Dipsacaceae & 91 & 26 & 117 \\
\hline Tropaeolaceae & 0 & 9 & 9 \\
\hline Violaceae & 16 & 13 & 29 \\
\hline Aceraceae & 1 & 0 & 1 \\
\hline Orchidaceae & 17 & 0 & 17 \\
\hline Cucurbitaceae & 2 & 0 & 2 \\
\hline Gentianaceae & 7 & 0 & 7 \\
\hline Cornaceae & 2 & 0 & 2 \\
\hline Araliaceae & 13 & 0 & 13 \\
\hline Cistaceae & 7 & 0 & 7 \\
\hline Cannabaceae & 1 & 0 & 1 \\
\hline Clusiaceae & 9 & 0 & 9 \\
\hline Aquifoliaceae & 5 & 0 & 5 \\
\hline Lythraceae & 18 & 0 & 18 \\
\hline Portulacaceae & 1 & 0 & 1 \\
\hline Plantaginaceae & 2 & 0 & 2 \\
\hline Polygalaceae & 3 & 0 & 3 \\
\hline Salicaceae & 12 & 0 & 12 \\
\hline Tiliaceae & 1 & 0 & 1 \\
\hline
\end{tabular}

75 plant families. Numbers are records for butterfly species.

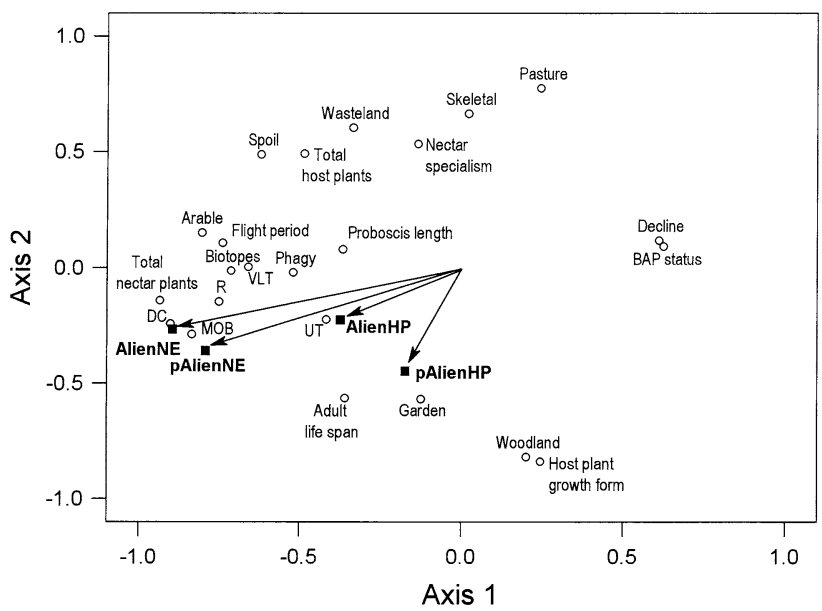

Fig. 3. Principal components plot of variables examined in relation to alien nectar plants and host plants (number: AlienNE, AlienHP, proportion: pAlienNE, pAlienHP); axis $133 \%$, axis 2 $20 \%$ variance. DC distribution cover for 1995-2005, R latitudinal range in Britain, MOB mobility, UT utilities, VLT voltinism. Nectar and host plant variables entered supplementary to analysis.

model was applied to actual number of alien host plants for the same predictors as proportional use of alien host plants (Table 6); three variables proved significant: phagy, mobility and garden biotope; butterfly species which are increasingly polyphagous, have higher mobility and with more larval host plants in gardens adopt more alien plants as host plants (Fig. 4).

\section{DISCUSSION}

The findings on use of alien plants as consumer resources confirm expectations based on earlier observations of nectar and host plant use among British butterflies (Porter et al., 1992). The list of host plants used by British butterflies is not only much shorter than that for nectar plants, as found also in California (Graves \& Shapiro, 2003), but there are close taxonomic associations between butterfly and host plant linked to plant chemical defences lacking in butterfly-nectar plant relationships (Ehrlich \& Raven, 1965). Relatively speaking, feeding butterfly adults are plant generalists whereas ovipositing adults and larvae are plant specialists. In line with this observation, the fraction of alien nectar plants is over double that for alien host plants; very few novel host plant families are observed $(\mathrm{N}=3)$ compared to novel nectar plant families $(\mathrm{N}=21)$.

The conservatism in host plant use compared to nectar use may also underlie the contrast in accounted variation between alien nectar and host plant exploitation by butterfly species. A large portion of the variation in alien nectar plant use is explained (80.5\%) and the link with wider nectar use (total number of plants) is closer than the link between alien host plant use and the total number of native host plants used. Key to alien nectar use are variables providing access to these sources (greater mobility, southern distributions, longer adult life span, host plants in garden biotopes). The picture is very different for alien 
TABLE 5. Regression parameters for variables influencing the proportion of alien plants used by British butterflies.

\begin{tabular}{lccccccc}
\hline $\begin{array}{l}\text { (a) Dependent var: } \\
\text { alien nectar plants (proportion) }\end{array}$ & $\beta$ & $\mathrm{SE}_{\beta}$ & $\mathrm{B}$ & $\mathrm{SE}_{\mathrm{B} .}$ & $\mathrm{t}_{(53)}$ & $\mathrm{R}^{2}$ change & $\mathrm{P}$ \\
\hline Intercept & - & - & -0.59 & 0.116 & -5.10 & - & $<0.0001$ \\
Mobility & 0.68 & 0.093 & 0.31 & 0.042 & 7.37 & 0.70 & $<0.0001$ \\
Garden biotope & 0.23 & 0.067 & 0.11 & 0.032 & 3.50 & 0.04 & 0.001 \\
Arable biotope & 0.25 & 0.078 & 0.21 & 0.065 & 3.24 & 0.02 & 0.002 \\
$\quad$ Latitude (median) & -0.19 & 0.078 & -0.00 & 0.002 & -2.48 & 0.03 & 0.016 \\
$\quad$ Adult lifespan & 0.17 & 0.067 & 0.03 & 0.014 & 2.46 & 0.02 & 0.017 \\
\hline (b) Dependent var: & $\beta$ & $\mathrm{SE}_{\beta}$ & $\mathrm{B}$ & $\mathrm{SE}_{\mathrm{B} .}$ & \multirow{2}{*}{$\mathrm{t}_{(57)}$} & $\mathrm{R}^{2}$ change & $\mathrm{P}$ \\
alien host plants (proportion) & $\beta$ & - & -0.55 & 0.166 & -3.33 & - & 0.001 \\
\hline Intercept & - & 0.110 & 0.23 & 0.051 & 4.54 & 0.25 & $<0.0001$ \\
$\quad$ Mobility & 0.50 & 0.110 & 0.69 & 0.328 & 2.12 & 0.05 & 0.039 \\
Host plant growth form & 0.23 & &
\end{tabular}

Proportion of alien nectar plants: $\mathrm{F}_{(5,53)}=43.63, \mathrm{P}<0.0001, \mathrm{R}^{2}=80.5 \%$, standard error of estimate 0.83 . Variables entered: distribution cover, latitude (median), mobility, adult life span, flight period, voltinism, proboscis length, arable and garden biotopes, and nectar specialism; regression weighted by number native nectar sources and the outlier A. iris removed. Proportion of alien host plants: $\mathrm{F}_{(2,57)}=12.64, \mathrm{P}<0.0001, \mathrm{R}^{2}=30.0 \%$, standard error of estimate $=0.68$. Variables entered: distribution cover, latitude (median), mobility, voltinism, phagy, larval host plant growth form, garden and woodland biotope. Regression weighted by number of native host plants.

host plants. Mobility still figures as the most significant variable for alien host plants used (proportions and numbers); other key variables differ for proportional use and numerical use of alien host plants - this distinction is a fundamental one in biological systems. Those butterfly species having a larger proportional use of alien host plants are ones having woody host plants, but butterfly species using a larger number of alien host plants tend to be polyphagous and have greater abundance of native host plants in gardens. But then, a little less than a third of variation in proportional alien host use is explained against $55 \%$ for numerical use. Underlying the differences in alien host plant and nectar plant use is nectar and leaf chemistry, certainly for species whose larvae are foliage feeders. Foliage chemistry imposes conservatism in host use linked to a chemical arms race (Dawkins \& Krebs, 1979), indications of which emerge in this study. Alien host plant use increases with woody plant growth forms not herbs; the quantitative defences (e.g. tannin) of the former are easier to overcome than the qualitative defences (allelochemicals) of the latter (Č́ízek et al., 2006). Furthermore, polyphagous species, which also

TABLE 6. Poisson log-link regression parameters for number of alien host plants.

\begin{tabular}{lrrrc}
\hline $\begin{array}{l}\text { Dependent var: } \\
\text { Alien host plants (number) }\end{array}$ & Estimate & $\begin{array}{c}\text { Standard } \\
\text { error }\end{array}$ & Wald & \multirow{2}{*}{ statistic } \\
\hline Intercept & -8.00 & 1.018 & 61.76 & $<0.0001$ \\
Phagy & 1.09 & 0.229 & 22.78 & $<0.0001$ \\
Mobility & 1.23 & 0.264 & 21.47 & $<0.0001$ \\
Garden biotope & 0.57 & 0.187 & 9.17 & 0.0 \\
Scale & 1.00 & 0.000 & & \\
\hline
\end{tabular}

Deviance 121.8 with 56 degrees of freedom; Loglikelihood = -91.08; Pearson $\chi^{2}=217.2$. Variables entered as in Table $5(b)$. No distinction on weighting regression. $\mathrm{R}^{2}=55 \%$ between observed and predicted values. tend to use more alien plants, are better adapted to a wider array of chemical defences.

Mobility has an expected influence on numbers of alien plants used. Increased mobility brings a butterfly species into greater potential contact with novel plants. For several reasons it is possible that the list of novel native and alien larval host plants is underestimated. Butterfly adults are more noticeable to observers than are butterfly larvae, which could well result in more novel nectar records compared to novel host plant records. Moreover, butterfly adults are more secretive when egg laying than they are when feeding. Finally, there may be a tendency amongst entomologists to search for larvae on well known host plants rather than on novel ones. What is known is that

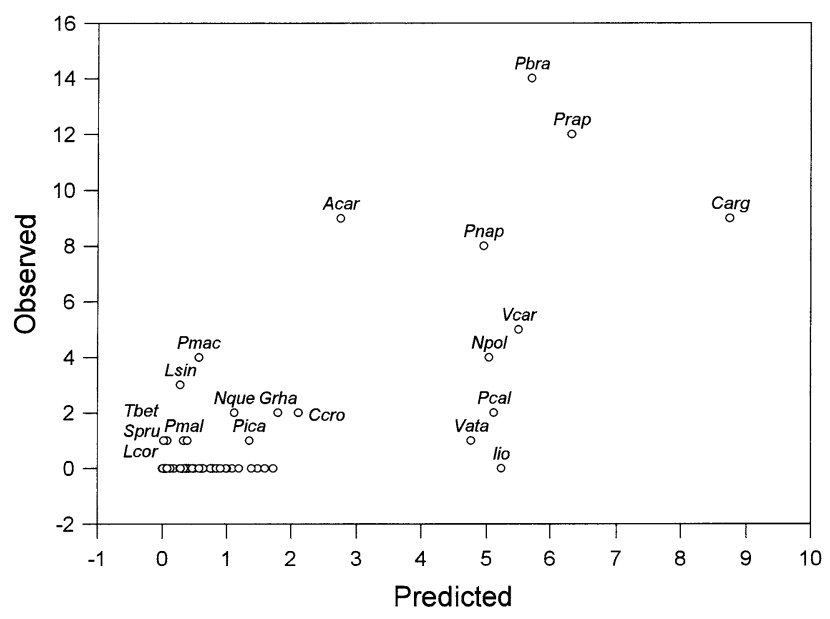

Fig. 4. Observed versus predicted number of alien host plants used by British butterflies from poisson log-link regression of alien host plants on phagy, mobility and host plant abundance in garden biotopes (see Table 5). Species labels (only those with $\geq 1$ observed values labelled) include the first letter of the genus and the first three letters of the species (see Table 2). 
butterfly species can expand their ranges using novel (alien) host plants introduced to novel biotopes (e.g. Euphydryas phaeton in North America,; Bowers et al., 1992; Gonepteryx rhamni along dual carriageways in North Wales; Gutiérrez \& Thomas, 2000); they can also adopt new host plants during range expansions (e.g. Aricia agestis on Geraniaceae; Kemp et al., 2008), the novel plants acting much as stepping stones for range expansion (Thomas et al., 2001). Currently, more than $32 \%$ (1057 of 3354 species listed in Kent, 1992) of vascular plants are well established as aliens in the United Kingdom. As such, with climate warming more observations can be expected not just of novel nectar plant exploitation but also of novel host plant use (Dennis, 1993).

The principal components analysis would suggest that alien plants are not of prime importance for butterfly conservation in the UK and are less important to species in marginal environments as in California (Graves \& Shapiro, 2003). Butterflies in decline and under threat (BAP priority status) use fewer alien host plants and nectar plants, though no study has been made on the extent to which butterfly species depend on alien resources in different localities (e.g. dependence on buddleia flowers in suburbia; Pieris species on Tropaeolum species as a host plant). Even so, specialist butterflies are known to use alien plants in North America (e.g. Euphydryas editha and E. phaeton; Bowers et al., 1992b, Singer et al., 1993) and in continental Europe (e.g. Neptis sappho; Jutzeler et al., 2000). This suggests another way to view this association between alien plants and threat status; limited use of novel (atypical) plants could itself be a measure of decline and threat; an increase in specialism on native plants and lower mobility occurring with biotope fragmentation and habitat loss. It may merely be one aspect of a collapse in the resource base species experience when phytophagous insects are forced into geographically-restricted refuges. If specialism is a positive feedback system, reinforcing further specialisation, then failure to use new plants may further limit the adaptability of affected species to changes of which they could otherwise take advantage. On the contrary, those species that can exploit novel and alien plants have access to novel biotopes generated by urbanisation and industrial development; lost species (e.g. Nymphalis polychloros; Asher et al., 2001) that have this capacity have opportunities to recolonise regions previously inhabited. Climatic warming in encouraging greater mobility of individual adults, as well as perhaps facilitating greater survival on secondary plants (e.g. Celastrina argiolus; Dennis, 1993), could well counter specialisation owing to fragmentation. There is then the question of whether alien plants are to be encouraged to enhance consumer resources for butterflies (e.g. alien disease resistant elms for Satyrium $w$-album)? Currently, knowledge of alien plant use is not adequate to make sound judgements; alien nectar use is accessible to casual observation and the records are extensive but lack qualification; however, indications are that records of alien host use deserve and require more careful study (Hardy et al., 2007), a precedent established in the study of Euphydryas species in America (Bowers et al., 1992a, b; Singer et al., 1993) and British G. rhamni (Gutiérrez \& Thomas, 2000) and also from clear indications of toxic effects on some California butterfly species (Shapiro \& Graves, 2003).

ACKNOWLEDGEMENTS. Our grateful thanks to all the many recorders for contributing to both databases, particularly to $\mathrm{M}$. Vickery, and to M. Konvička and two referees for their helpful comments. We are also grateful to D.G. Bishop for drawing our attention to publications on alien plants.

\section{REFERENCES}

Asher J., Warren M., Fox R., Harding P., Jeffcoate G. \& JefFCOATE S. 2001: The Millennium Atlas of Butterflies in Britain and Ireland. Oxford University Press, Oxford, $433 \mathrm{pp}$.

Bowers M.D., Collinge S.K., Gamble S.E. \& Schmitt J. 1992a: Effects of genotype, habitat, and seasonal variation on iridoid glycoside content of Plantago lanceolata (Plantaginaceae) and the implications for insect herbivores. Oecologia 91: 201-207.

Bowers M.D., Stamp N.E. \& Collinge S.K. 1992b: Early stage of host range expansion by a specialist herbivore, Euphydryas phaeton (Nymphalidae). Ecology 73: 526-536.

Chytry M., Maskell L.C., Pino J., Pysek P., Vila M., Font X. \& SMART S.M. 2008: Habitat invasions by alien plants: a quantitative comparison among Mediterranean, subcontinental and oceanic regions of Europe. J. Appl. Ecol. 45: 448-458.

Č́žEK L., Fric Z. \& KonviČKa M. 2006: Host plant defences and voltinism in European butterflies. Ecol. Entomol. 31: 337-344.

CORBET S.A. 2000: Butterfly nectaring flowers: butterfly morphology and flower form. Entomol. Exp. Appl. 96: 289-298.

Dawkins R. \& Krebs J.R. 1979: Arms races between and within species. Proc. R. Soc. Lond. (B) 205: 489-511.

DenNis R.L.H. 1977: The British Butterflies. Their Origin and Establishment. Classey, Faringdon, 318 pp.

Dennis R.L.H. 1993: Butterflies and Climate Change. Manchester University Press, Manchester, $302 \mathrm{pp}$.

Dennis R.L.H., Hodgson J.G., Grenyer R., Shreeve T.G. \& Roy D.B. 2004: Host plants and butterfly biology. Do host-plant strategies drive butterfly status? Ecol. Entomol. 29: 12-26.

Dennis R.L.H., Hardy P.B. \& Shreeve T.G. 2008: The importance of resource databanks for conserving insects: a butterfly biology perspective. J. Insect Conserv. DOI 10.1007.s10841007-9112-7.

DiTommaso A., Lawlor F.M. \& Darbyshire S.J. 2005: The biology of invasive alien plants in Canada. 2. Cynanchum rossicum (Kleopow) Borhidi $[=$ Vincetoxicum rossicum (Kleopow) Barbar.] and Cynanchum louiseae (L.) Kartesz \& Gandhi [= Vincetoxicum nigrum (L.) Moench]. Can. J. Plant Sci. 85: 243-263.

EhrLich P.R. \& RAVEN P.H. 1965: Butterflies and plants: a study in coevolution. Evolution 18: 586-608.

Fox R., Asher J., Brereton T.M., Roy D.B. \& Warren M.S. 2006: The State of Butterflies in Britain and Ireland. Pisces Publications, Newbury, 112 pp.

Foxcroft L.C., Richardson D.M. \& Wilson J.R.U. 2008: Ornamental plants as invasive aliens: problems and solutions in Kruger National Park, South Africa. Environ. Manag. 41: $32-51$. 
Godwin H. 1984: History of the British Flora. A Factual Basis for Phytogeography. Cambridge University Press, Cambridge, $541 \mathrm{pp}$.

Graves S.D. \& Shapiro A.M. 2003: Exotics as host plants of the California butterfly fauna. Biol. Conserv. 110: 413-433.

GutiérRez D. \& Thomas C.D. 2000: Marginal range expansion in a host-limited butterfly species Gonepteryx rhamni. Ecol. Entomol. 25: 165-170.

Hardy P.B. \& DenNIS R.L.H. 2008: Shifting butterfly habitats and biotope affiliations accompany use of alien nectar sources after deforestation. Acta Zool. Sin. 54: 77-83.

Hardy P.B., Sparks T.H., IsaAC N.J.B. \& DenNIs R.L.H. 2007: Resource databanks for butterflies: the state of British larval and adult food source data and implications for butterfly conservation. Biol. Conserv. 138: 440-452.

Kemp R., Hardy P.B., Roy D., Dennis R.L.H. 2008: The relative exploitation of annuals as larval host plants by phytophagous Lepidoptera. J. Nat. Hist. 42: 1079-1093.

Jutzeler D., Hoettinger H., Malicky M., Rebeusek F., Sala G. \& VerovNIK R. 2000: Biology of Neptis sappho (Pallas, 1771) based on the monograph by Timpe \& Timpe (1993) and its actual distribution and conservation status in Austria, Italy and Slovenia (Lepidoptera: Nymphalidae). Linn. Belg. 17: 315-330.

Kent D.H. 1992: List of Vascular Plants of the British Isles. Botanical Society of the British Isles, London, $384 \mathrm{pp}$.

Kenis M., Rabitsch W., Auger-Rozenberg M.A. \& Roques A. 2007: How can alien species inventories and interception data help us prevent insect invasions? Bull. Entomol. Res. 97: 489-502.

Porter K., Steel C.A. \& Thomas J.A. 1992: Butterflies and communities. In Dennis R.L.H. (ed.) Ecology of Butterflies in Britain. Oxford University Press, Oxford, pp. 139-177.
Pryke S.R. \& Samways M.J. 2003: Quality of remnant indigenous grassland linkages for adult butterflies (Lepidoptera) in an afforested African landscape. Biodiv. Conserv. 12: 1985-2004.

Rebelo A.G. 1992: Red Data Book species in the Cape Floristic Region - threats, prioirities and target species. Trans. R. Soc. Sth. Afr. 48: 55-86.

RickLefs R.E., Guo Q.F. \& Qian H. 2008: Growth form and distribution of introduced plants in their native and non-native ranges in Eastern Asia and North America. Divers. Distrib. 14: $381-386$.

Singer M.C., Thomas C.D. \& Parmesan C. 1993: Rapid humaninduced evolution of insect host associations. Nature 366: 681-683.

Smith R.M., Baker R.H.A., Malumphy C.P., Hockland S., Hammon R.P., Ostoja-Starzewsin J.C. \& Collins D.W. 2007: Recent non-native invertebrate plant pest establishments in Great Britain: origins, pathways, and trends. Agri. For. Entomol. 9: 307-326.

StaCe C. 1997: New Flora of the British Isles. Cambridge University Press, Cambridge, $1130 \mathrm{pp}$.

Thomas C.D., Bodsworth E.J., Wilson R.J., Simmons A.D., Davies Z.G., Musche M. \& ConRadt L. 2001: Ecological and evolutionary processes at expanding range margins. Nature 411: $577-581$.

Wells F.H. \& Lauenroth W.K. 2007: The potential for horses to disperse alien plants along recreational trails. Rang. Ecol. Manag. 60: 574-577.

WiKLUND C. 1981: Generalist vs. specialist oviposition behaviour in Papilio machaon (Lepidoptera) and functional aspects on the hierarchy of oviposition preferences. Oikos 36: 163-170.

Received March 26, 2008; revised and accepted May 5, 2008 